Article

\title{
Bio-Aerosols Negatively Affect Prochlorococcus in Oligotrophic Aerosol-Rich Marine Regions
}

\author{
Eyal Rahav ${ }^{1, *}$, Adina Paytan ${ }^{2}$, Esra Mescioglu ${ }^{3}{ }^{-}$, Edo Bar-Zeev $^{4}$, Francisca Martínez Ruiz $^{5}$, \\ Peng Xian ${ }^{6}$ and Barak Herut ${ }^{1}$ (D) \\ 1 Israel Oceanographic and Limnological Research, National Institute of Oceanography, \\ Tel-Shikmona 8030, Haifa 3108000, Israel; barak@ocean.org.il \\ 2 Institute of Marine Science, University of California, Santa Cruz, CA 95064, USA; apaytan@ucsc.edu \\ 3 Earth and Planetary Sciences Department, University of California, Santa Cruz, CA 95064, USA; \\ emesciog@ucsc.edu \\ 4 Department of Environmental Hydrology and Microbiology, Zuckerberg Institute for Water Research, \\ Ben-Gurion University of the Negev, Sede-Boqer Campus 84990, Israel; barzeeve@bgu.ac.il \\ 5 Instituto Andaluz de Ciencias de la Tierra (CSIC-UGR), Avda. de las Palmeras 4, \\ 18100 Granada Armilla, Spain; fmruiz@ugr.es \\ 6 Marine Meteorology Division, Naval Research Laboratory, 7 Grace Hopper Avenue, \\ Monterey, CA 93940, USA; peng.xian@nrlmry.navy.mil \\ * Correspondence: eyal.rahav@ocean.org.il
}

Received: 26 April 2020; Accepted: 19 May 2020; Published: 22 May 2020

check for updates

\begin{abstract}
The marine cyanobacterium Prochlorococcus is a dominant photoautotroph in many oligotrophic Low-Nutrients-Low-Chlorophyll (LNLC) regions. While the chemical impact of aerosols upon interaction with surface seawater was documented in numerous studies, we show that Prochlorococcus cells are affected also by bio-aerosols (potentially biological agents in the dust/aerosols such as membrane-bound extracellular vesicles, small-size bacteria and/or viruses), resulting in lower surface seawater abundances in the oligotrophic Mediterranean Sea. We conducted experimental amendments of 'live' aerosol/dust particles and aerosol filtrates $(<0.22-\mu \mathrm{m})$ to surface Southeastern Mediterranean seawater or to pure Prochlorococcus cultures (MED4). Results show a significant decline in cell biomass $(<90 \%)$, while UV-sterilized aerosols elicited a much weaker and non-significant response $(\sim 10 \%)$. We suggest that the difference is due to a negative effect of bio-aerosols specific to Prochlorococcus. Accordingly, the dominance of Synechococcus over Prochlorococcus throughout the surface Mediterranean Sea (observed mainly in spring when atmospheric aerosol levels are relatively high) and the lack of spatial westward gradient in Prochlorococcus biomass as typically observed for chlorophyll- $a$ or other cyanobacteria may be attributed, at least to some extent, to the impact of bio-aerosol deposition across the basin. Predictions for enhanced desertification and increased dust emissions may intensify the transport and potential impact of bio-aerosols in LNLC marine systems.
\end{abstract}

Keywords: aerosols; Saharan Dust; Prochlorococcus; Mediterranean Sea

\section{Introduction}

Marine cyanobacteria of the genus Prochlorococcus comprise a large fraction of the photoautotrophic biomass and are major contributors to gross primary production in many oligotrophic Low Nutrients Low Chlorophyll (LNLC) regions [1-3]. One of the major controls on the spatiotemporal distribution of cyanobacteria such as Prochlorococcus, especially in oligotrophic systems, is viral infection [4] and/or bacterial vesicles [5]. Viral lysis accounts for $>50 \%$ of the total cyanobacterial cell loss in the oligotrophic subtropical northeastern Atlantic [6] and Prochlorococcus vesicles can support the growth of heterotrophic bacteria, which have been shown to contribute to virulence [7] and cellular defense mechanisms [8]. 
Another important constraint on Prochlorococcus biomass is nutrient bioavailability $[9,10]$. Several experimental and modelling studies demonstrated that the supply of nutrients and trace metals via atmospheric deposition may increase the biomass and carbon fixation rates of marine primary producers, including cyanobacteria, thus playing a significant role in the nutrition and ecology of LNLC regions [11,12]. Other studies, however, reported specific reduction in Prochlorococcus activity/biomass following aerosol amendment in the tropical Northeast Atlantic Ocean, the Western Atlantic, the Pacific Ocean, the Red Sea and the Southeast Mediterranean Sea [13-17]. These trends were attributed to the potential release of toxic levels of trace metals from the aerosols [18].

In addition to micro- and macronutrients, aerosols also deliver airborne microbes including bacteria, archaea, fungi and viruses [19-25], some of which remain viable during transport and post-deposition [26]. Sea-spray and viral aerosolization [27], as well as material transport from land (e.g., mineral dust) [22], are typical sources of bio-aerosols found over the ocean. We hypothesized that aerosols constitute a transport vector for bacteria, vesicles and viruses and may therefore play an important ecological role, especially in oligotrophic marine provinces where the standing stock of biomass is low. Such regions consist $\sim 60 \%$ of the global ocean surface area [11].

Here, we use enrichment microcosm experiments to show that airborne biological agents such as membrane-bound extracellular vesicles, small-size bacteria $(<0.22 \mu \mathrm{m})$ and/or viruses (hereafter referred to as bio-aerosols), along with airborne soluble chemical constituents, negatively affect Prochlorococcus abundance. We further suggest that the relatively high mineral-aerosol content in the atmosphere above the Mediterranean basin may explain the overall low and homogenous Prochlorococcus abundance in surface water throughout the basin. This is in contrast to the typical east-west increase in total phytoplankton (e.g., chlorophyll-a) or other cyanobacteria (i.e., Synechococcus) which are responding to nutrient availability and are less affected by the aerosols [28].

\section{Material and Methods}

\subsection{Aerosol Collection}

Dry deposition of total suspended particles (TSP) which includes mineral dust and anthropogenic constituents was collected on 15 February, 2015, during a major dust storm event using a pre-cleaned glass deposition plate located on the Israel Oceanographic \& Limnological Research institute (ILOR) roof 20 meters from the coast (Latitude $32.28 \mathrm{~N}$, Longitude $34.95 \mathrm{E}$ ). Aerosols were removed from the plate using a clean plastic knife, transferred into pre-washed $(10 \%$ hydrochloric acid) sterile $2 \mathrm{~mL}$ plastic tubes and stored at $-20{ }^{\circ} \mathrm{C}$ until further analyses. In addition, TSP were collected daily (every $24 \mathrm{~h}$ ) by a high-volume sampler (Eco-tech High Volume Sampler, $60 \mathrm{~m}^{3} \mathrm{~h}^{-1}$ ) at different sites across the Mediterranean basin onboard the research vessel METEOR (cruise number M84/3) using pre-weighted and acid-washed Whatman 41-filters (high-quality cotton linters, GE Healthcare) during April 2011 (Longitude $34.05 \mathrm{E}$ to Longitude $5.38 \mathrm{~W}$, total of 21 filters). The filters were stored in $-20{ }^{\circ} \mathrm{C}$ until analyses [24]. Three-day back trajectories arriving at 100, 250 and $500 \mathrm{~m}$ altitude levels were calculated using the HYSPLIT model from the Air-Resources Laboratory, NOAA (Figure S1). Bulk Aluminum ( $\mathrm{Al}$ ) concentrations were measured after filter digestions [29] by an Agilent 280FS AA atomic adsorption spectrometer.

Aerosols collected in the Southeastern Mediterranean Sea during a dust storm event that originated in the Saharan Desert and had a prolonged marine transport prior to deposition ( $\sim 3$ days) were used in a bioassay incubation experiment (Figure S1). Based on the Al concentration of the collected aerosol (7.6\% dry weight), a settling velocity of $1.8 \mathrm{~cm} \mathrm{~s}^{-1}$ [30], and the aerosol's weight normalized to the collection filter area and air volume pumped (1.40 $\mathrm{mg}_{\text {dust }} \mathrm{m}^{-3}$ air), we calculated that $\sim 0.2 \mathrm{mg} \mathrm{L}^{-1}$ of dust was deposited in the upper $1 \mathrm{~m}$ mixed layer during this event. Previous nutrient leaching measurements of Saharan desert aerosol samples collected at our study site contained $\sim 20 \mathrm{nmol} \mathrm{NOx}$ and $\sim 2 \mathrm{nmol} \mathrm{PO}_{4}$ per mg dust (i.e., [31,32]). While leached nutrients were not measured for the aerosol particles collected in February 2015 (which were used in the microcosm experiments), we expect that 
the aerosol had overall similar chemical characteristics. Therefore, the addition of $1.5 \mathrm{mg} \mathrm{L}^{-1}$ likely resulted in a net increase of $\sim 30 \mathrm{nM} \mathrm{NOx}$ and $\sim 3 \mathrm{nM} \mathrm{PO}_{4}$. Given the ultra-oligotrophic characteristics of the Southeastern Mediterranean Sea [33-35], such external nutrient addition from aerosol is expected to increase the microbial activity and biomass [31,36,37].

\subsection{Aerosol Re-Analysis Product}

The aerosol optical depth (AOD) data was calculated from the Navy Aerosol Analysis and Prediction System (NAAPS) global model using $1 \times 1$ degree and 6-hourly $550 \mathrm{~nm}$ re-analyses as described in Lynch and co-authors [38].

\subsection{Bioassay Experiments of Aerosol Additions to Seawater}

Aerosol enrichment microcosm experiment was carried out in triplicate 1-L Nalgene bottles using surface seawater collected in a coastal site in the Southeast Mediterranean Sea. The main objective of the experiments was to examine whether pico-phytoplankton abundance changes with the addition of the collected aerosol and to compare the response to UV-treated aerosols to assess the effect of the biological component of the aerosols. We also investigated the dose-dependence of the response. Aerosols collected on 15 February, 2015, were added at different concentrations $\left(0.2-3.0 \mathrm{mg} \mathrm{L}^{-1}\right)$ to Mediterranean coastal surface seawater $(\sim 0.5 \mathrm{~m}$, Latitude $32.84 \mathrm{~N}$, Longitude $34.95 \mathrm{E})$ and the microcosm bottles were placed in a seawater flow-through tank $\left(\sim 3 \mathrm{~m}^{3}\right)$ to maintain ambient temperature and light for $48 \mathrm{~h}$. Parallel, a UV-killed treatment of the same aerosol was also added to coastal seawater to eliminate airborne microbes (Figure S2), and therefore any change observed in cells abundance is mainly attributed to the non-biological properties of the aerosol (e.g., leached trace metals). Although the particle load of dust/aerosols, especially during large storms, can attenuate UV by more than $50 \%$ and shelter the airborne biological components against UV damage [39], our UV treatment is prolonged and intense, ensuring a significant decline in any biological component associated with the dust/aerosol (Figure S2 and see $[17,23,32]$ ). It is to be noted, though, that the UV treatment may cause some alterations in the aerosol chemistry, namely the breakdown of organics, redox chemistry of metals, destruction of metal-binding ligands, and changes in the molecular form of nutrients. In order to test if the UV treatment we used induced any chemical alterations, we run an experiment comparing the changes in Prochlorococcus abundance when using a gamma-ray aerosol treatment vs. UV aerosol treatment vs. autoclave (the gamma-ray treatment should not have any effect on aerosol chemistry). Our results show that both the UV- and gamma-treated aerosols induced a similar response, namely, the same trends in Prochlorococcus abundance were observed following their addition (Figure 1). This is in contrast to using autoclave sterilization that likely changed carbon chemistry/availability of different molecules and therefore may 'artificially' affect Prochlorococcus cells resulting in skewed trends. Therefore, while it is possible that the changes observed in Prochlorococcus abundance following UV-killed aerosol addition may be partly triggered by chemical modification to the aerosol particles due to the UV radiation, these changes are likely minimal.

Subsamples from each treatment were taken from the microcosm bottles at 0, 3, 6, 12, 36 and $49 \mathrm{~h}$ post addition for picophytoplankton abundance measurements using flow-cytometry. Blank treatments contained only seawater without any aerosol amendment were also included. The plain non UV-treated aerosols added leached nutrients, trace-metals and airborne microbes (prokaryotes, fungi, eukaryotic algae and viruses) that are associate with the particles to the seawater, whereas in the UV-treated aerosols (referred to as 'UV-killed' herein) the airborne microbes were damaged by the UV light, hence only leached nutrients and trace-metals were added [23]. The difference between the two treatments ('live aerosol' vs. 'killed aerosol'), therefore, represents the contribution of airborne microbes. The net contribution of airborne microbes was calculated as follows:

$$
\text { Net airborne contribution }(\%)=\frac{(\mathrm{L}-\mathrm{K})}{\mathrm{K}} \times 100
$$


where 'L' stands for the changes recorded in Prochlorococcus abundance following 'live aerosols' addition compared with the unamended control, and ' $\mathrm{K}$ ' stands for the changes found post 'UV-killed' aerosol addition relative to the control.
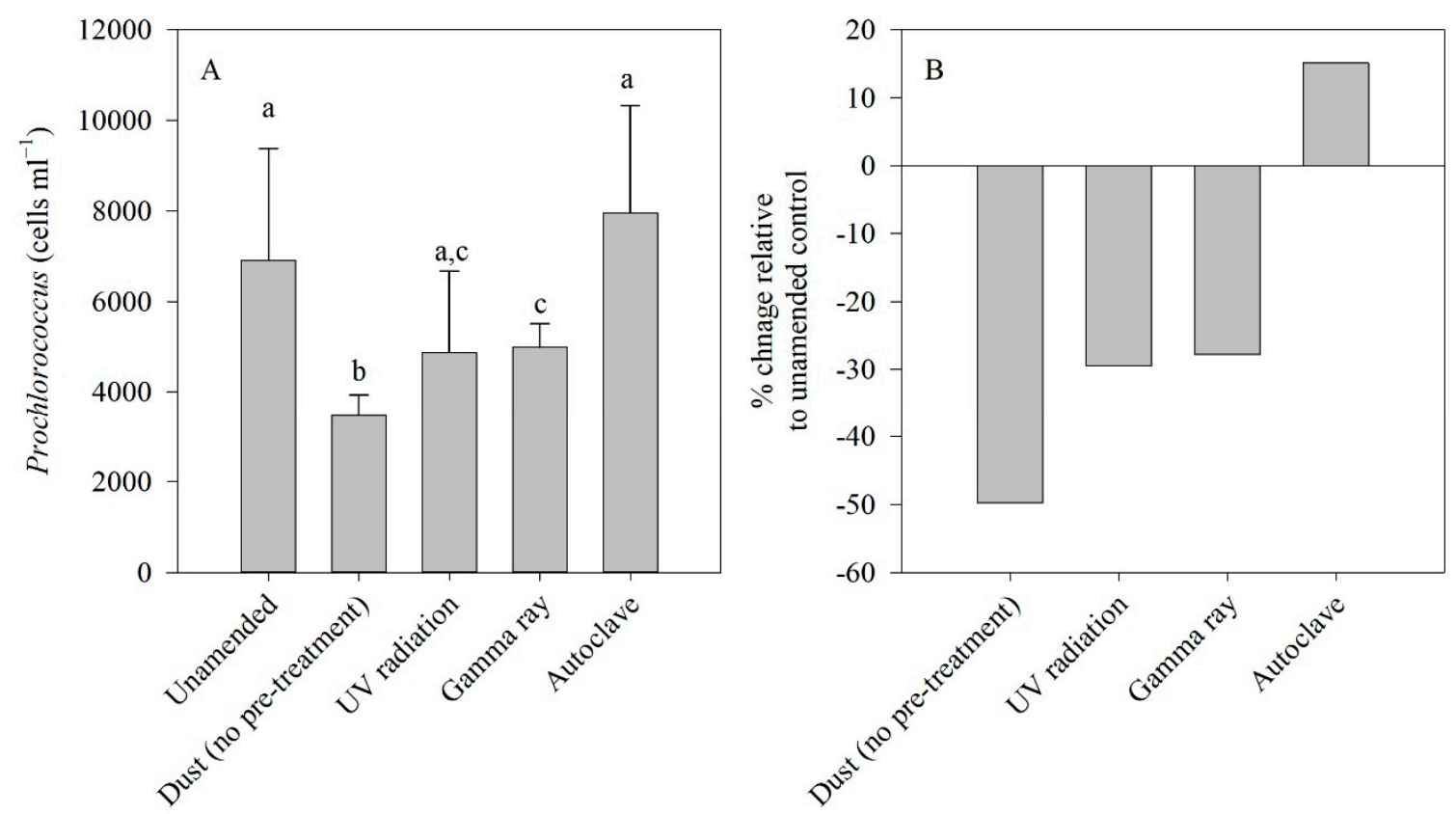

Figure 1. The effect of different aerosol's sterilization approaches on Prochlorococcus abundance. (A) Changes in the abundance of Prochlorococcus following $\sim 0.8 \mathrm{mg} \mathrm{L}^{-1}$ aerosol addition; (B) The net $\%$ change relative to the unamended controls. The letters above the column represents the statistical differences between treatments (Analysis of variance (ANOVA), $p<0.05, \mathrm{n}=3$ ).

\subsection{Aerosol Filtrate Addition to Prochlorococcus MED4 Cultures}

Two independent experiments of filtrate additions to Prochlorococcus cultures of axenic MED4 cells grown in Pro99 media (initial abundance of $\sim 2 \times 10^{5}$ cells $\mathrm{mL}^{-1}$ in all bottles) [40] were carried out: one in April and the other in June 2017. The results presented are the average of these experiments. The aim of these experiments was to examine if and how small-scale biological agents leached from the aerosols affect Prochlorococcus MED4 abundance. To this end, the same aerosol collected in February 2015 was used and the following experimental setup was carried out (Figure 2): [1] No addition (i.e., only cultured Prochlorococcus MED4 cells); [2] $1.5 \mathrm{mg} \mathrm{L}^{-1}$ 'live' aerosol addition (containing nutrients and airborne microbes and other biological agents); and [3] $1.5 \mathrm{mg} \mathrm{L}^{-1}$ UV-killed aerosol addition (containing only chemical constitutes, cell and viral debris). The bottles were incubated for $24 \mathrm{~h}$ under low light conditions ( $50 \mu \mathrm{mol}$ quanta $\mathrm{m}^{-2} \mathrm{~s}^{-1}$, LI-COR LI-250A, 12:12 h dark:light) in a temperature-controlled room $\left(20^{\circ} \mathrm{C}\right)$. At the conclusion of the experiment, each bottle was filtered using a sterile $0.22-\mu \mathrm{m}$ filter (Millex GV) and the filtrate (dissolved fraction which includes the $<0.22-\mu \mathrm{m}$ particles potentially including viruses and other sub-micron biological agents) was collected and transferred to a fresh Prochlorococcus MED4 culture at a 1:9 filtrate to media ratio (v:v). The bottles (containing fresh cultures + relevant filtrate) were incubated for additional $24 \mathrm{~h}$ under the same conditions described above. Prochlorococcus abundance was quantified using flow-cytometry at the start and conclusion of each experiment. We postulated that any response observed following the addition of the 'live' filtrate may be attributed to the chemical components in the aerosol filtrate (e.g., N, $\mathrm{P})$, as well as biological airborne agents such as viruses, extracellular vesicles and/or small-sized bacteria $(<0.22-\mu \mathrm{m})$. In contrast, a similar addition with the 'UV-killed' dust filtrate (instead of 'live-dust' filtrate) will only induce a response related to the chemical components of the added aerosol filtrate on Prochlorococcus MED4 abundance. 
Prochlorococcus culture
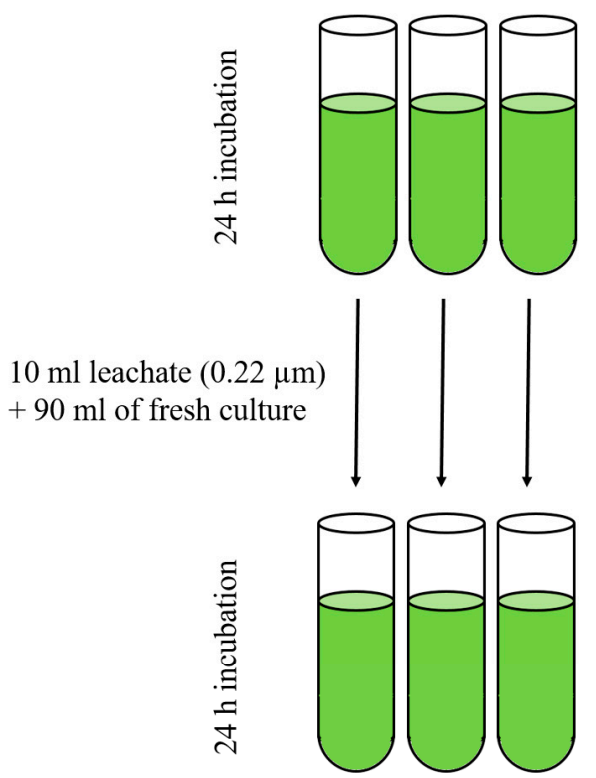

Prochlorococcus culture $+1.5 \mathrm{mg} / \mathrm{L}$ 'live-dust'
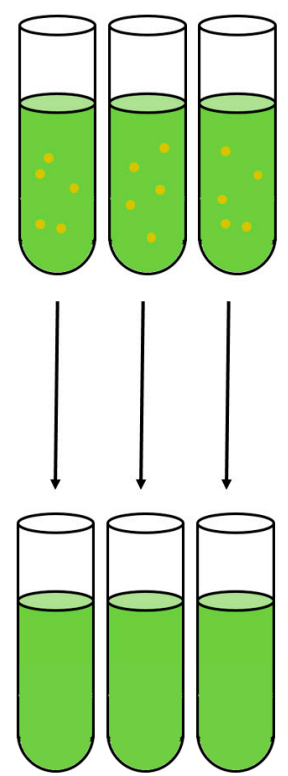

Prochlorococcus culture $+1.5 \mathrm{mg} / \mathrm{L}$ 'UV-Killed dust'
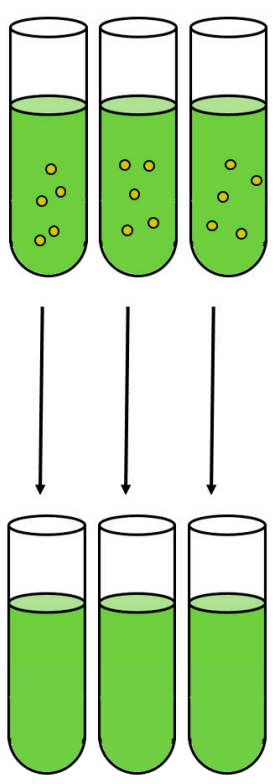

\section{No significant change in cell abundance}

Small decline in cell abundance

Figure 2. An illustration showing the experimental design with Prochlorococcus MED4 cultures. The following treatments were carried out in triplicates: [1] No addition (control); [2] Addition of $1.5 \mathrm{mg} \mathrm{L}^{-1}$ aerosol (orange dots); and [3] Addition of $1.5 \mathrm{mg} \mathrm{L}^{-1}$ UV-killed aerosol (orange dots with black outline). The bottles were incubated for $24 \mathrm{~h}$ under controlled light and temperature. At the conclusion of the experiment, each bottle was filtered through a $0.22-\mu \mathrm{m}$ filter and $10 \mathrm{~mL}$ of the filtrate was transferred to $90 \mathrm{~mL}$ of fresh Prochlorococcus MED4 culture. The bottles were incubated for additional $24 \mathrm{~h}$ under the same conditions. Prochlorococcus abundance was quantified using flow-cytometry at the start and conclusion of each experiment.

\subsection{Picophytoplankton Abundance and Characterization}

Seawater/culture samples $(1.8 \mathrm{~mL})$ were fixed with ultra-pure glutaraldehyde (Sigma-Aldrich G7651, flow-cytometry grade, final concentration $0.02 \%$ ) and run in an Attune®Acoustic Focusing Flow Cytometer (Applied Biosystems) equipped with 488- and 405-nm lasers to determine picophytoplankton abundance [41]. Taxonomic discrimination was based on orange fluorescence of phycoerythrin (cyanobacteria), red fluorescence (chlorophyll-a), side scatter, and forward scatter [42]. Beads $(0.93 \mu \mathrm{m}$, Polysciences) were used for size standardization.

\subsection{Transmission Electron Microscopy (TEM) of Bio-Aerosol Particles}

Representative samples of the Prochlorococcus cultures were fixed with glutaraldehydeformaldehyde solution and embedded in epoxy resin after dehydration. Ultrathin (50-70 nm) sections were cut from the resin (10 from each treatment), collected onto copper grids (300-nm mesh), and stained with uranyl for TEM observations. The grids were examined under a Carl Zeiss SMT LIBRA 120 PLUS operated at $120 \mathrm{kV}$ and for analytical electron microscopy (AEM) under a FEI TITAN G2 60-300 microscope (FEI, USA) with a high brightness electron gun (X-FEG) operated at 300kV and equipped with a SUPER-X silicon-drift windowless EDX detector (at CIC, University of Granada). 


\section{Results}

\subsection{Effects of Aerosol Filtrate on Prochlorococcus MED4 Cultures}

The 'UV-killed aerosol' treatment represents the response to aerosol derived soluble nutrients, trace metals and cell and viral debris, while the 'live aerosol' treatment includes both the chemical constitutes and airborne microorganisms and other biological agents such as viruses and cell vesicles (Figure S2). Both aerosol amendments resulted in a decrease in cell density; however, in the 'live aerosol' treatment the decrease was of $\sim 33 \%$ relative to the non-amended control (ANOVA, $p<0.05$ ), while the 'UV-killed aerosol' treatment resulted in a non-significant decrease of $\sim 12 \%$ relative to the non-amended control (ANOVA, $p>0.05$ ) (Figure 3A,B). The 'UV-killed aerosol' filtrate addition did not induce significant change in Prochlorococcus cells' abundance (ANOVA, $p>0.05$ ), while the 'live aerosol' filtrate addition resulted in a significant decrease (32\%) in Prochlorococcus abundance (ANOVA, $p>0.01$ ) (Figure 3A,B). Transmission electron microscopy (TEM) images of the Prochlorococcus cells from these cultures showed icosahedra-shape bacteriophages present in the aerosol particles and infected cells seen only in the 'live aerosol' bioassay, while no infected cells were observed in the 'UV-killed aerosol' or the non-amended control treatments (Figure 4). However, we cannot rule out that other small-sized cellular biological agents such as membrane-bound extracellular vesicles or small-sized bacteria (i.e., Pelagibacter) may have also affected the trends observed (see discussion below).
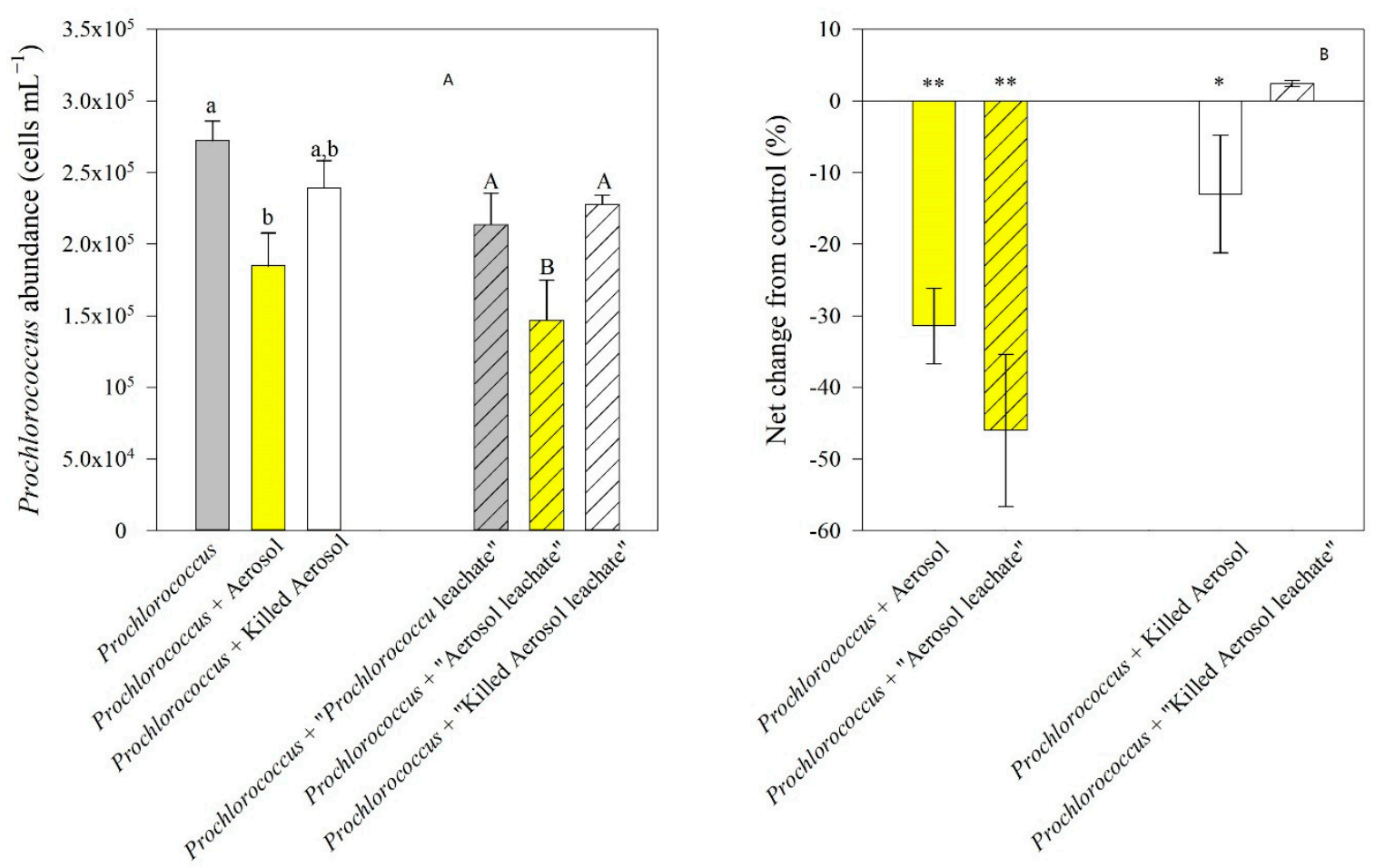

Figure 3. The effect of 'live' or 'UV-killed' aerosol addition on Prochlorococcus MED4 abundance. (A) Changes in the abundance of Prochlorococcus MED4 cultures following $1.5 \mathrm{mg} \mathrm{L}^{-1}$ aerosol addition (24 h post addition of aerosol or aerosol's filtrate); (B) The net \% change relative to the unamended controls. Striped columns represent the addition of filtered $(0.22 \mu \mathrm{m})$ culture ('control', 'live aerosol' or 'UV-killed aerosol') to fresh Prochlorococcus culture (10\% filtrate and $90 \%$ fresh culture). The letters above the column represents the statistical differences between treatments (ANOVA, $p<0.05, \mathrm{n}=3-6$ ). ${ }^{*} p<0.05,{ }^{* *} p<0.01$. 


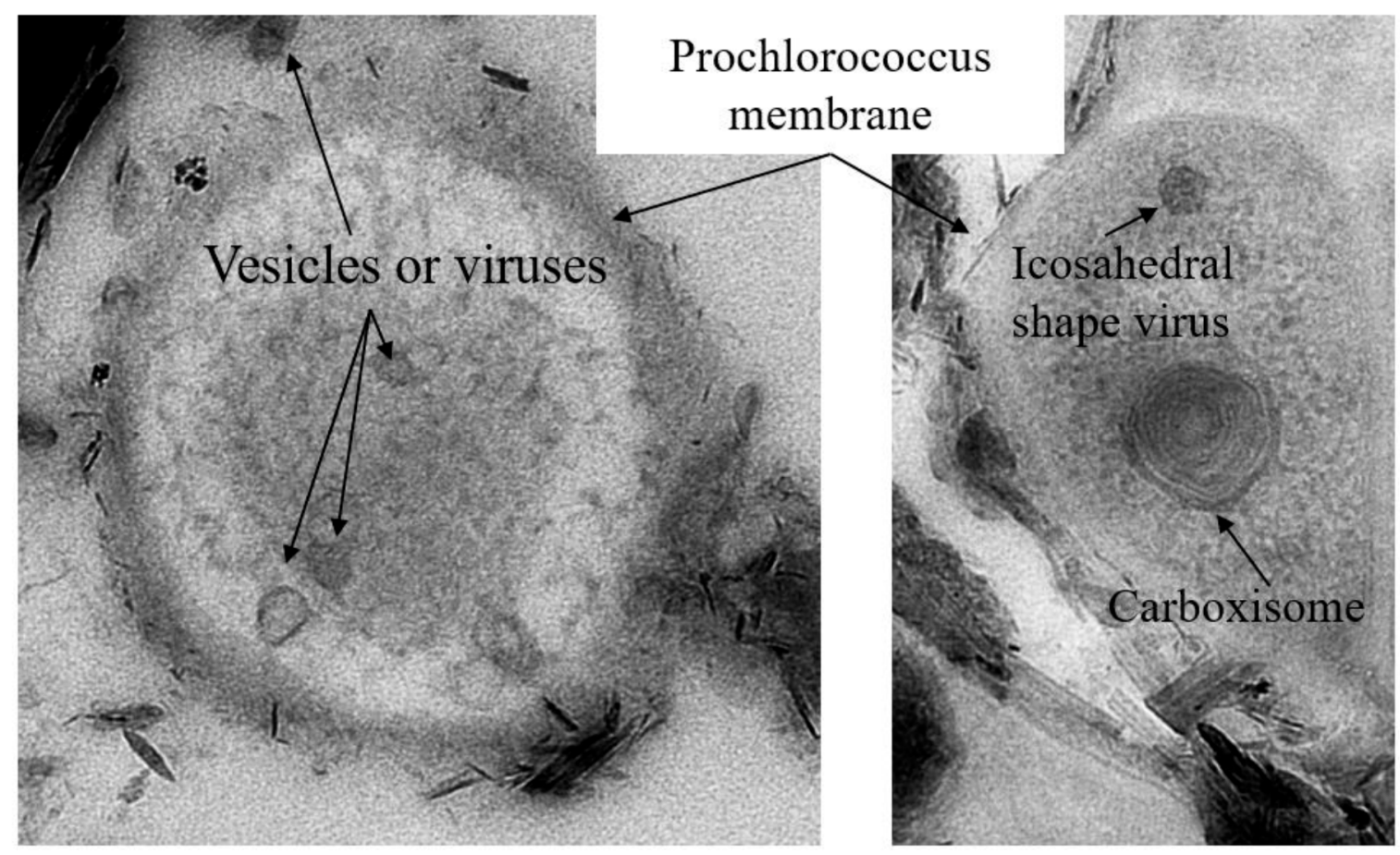

Figure 4. Transmission electron microscopy images showing icosahedral shape structure and/or vesicles embedded within a Prochlorococcus MED4 cell following aerosol addition. Note we did not observe infected cells in the 'UV-killed aerosol' or the non-amended control treatments.

\subsection{Dose-Dependent Aerosol Addition to Coastal Seawater Pico-Phytoplankyton Populations}

A similar deleterious effect on Prochlorococcus cells following aerosol amendment to coastal Southeastern Mediterranean Sea surface water was observed (Figure 5). Prochlorococcus abundances declined dramatically over $48 \mathrm{~h}$ following a concentration-gradient from low $\left(0.2 \mathrm{mg} \mathrm{L}^{-1}\right)$ to high (3.0 $\mathrm{mg} \mathrm{L}^{-1}$ ) aerosol additions, while Synechococcus and picoeukaryotes abundance were overall less affected (Figure 5). The decrease in Prochlorococcus was dose-dependent, ranging from 25\% reduction in cells following the low aerosol addition $\left(0.2 \mathrm{mg} \mathrm{L}^{-1}\right)$ and up to $70 \%$ reduction in cells abundance following high aerosol addition $\left(3.0 \mathrm{mg} \mathrm{L}^{-1}\right)$. These effects were significantly reduced once the aerosol sample was treated with prolonged and intense UV-radiation before addition to damage the 'biological component' in the aerosol, with only $20 \%$ decrease in abundance for the high 'UV-killed aerosol' addition (Figure 5). Contrary, Synechococcus and picoeukaryotes were similarly affected as in the 'live-dust' addition (Figure 5). We postulate that airborne component/s within the aerosol used, presumably viruses, small-sized bacteria and/or membrane vesicles, accounted for up to $90 \%$ of the change recorded in 'live aerosol' additions (Figure 5C, calculated as the net difference between the 'live' and 'killed' aerosols divided by the overall change recorded post 'live' aerosol addition). These results are in agreement with field observations in the same area [14], as well as in other oceanic systems [13,15-17]. 

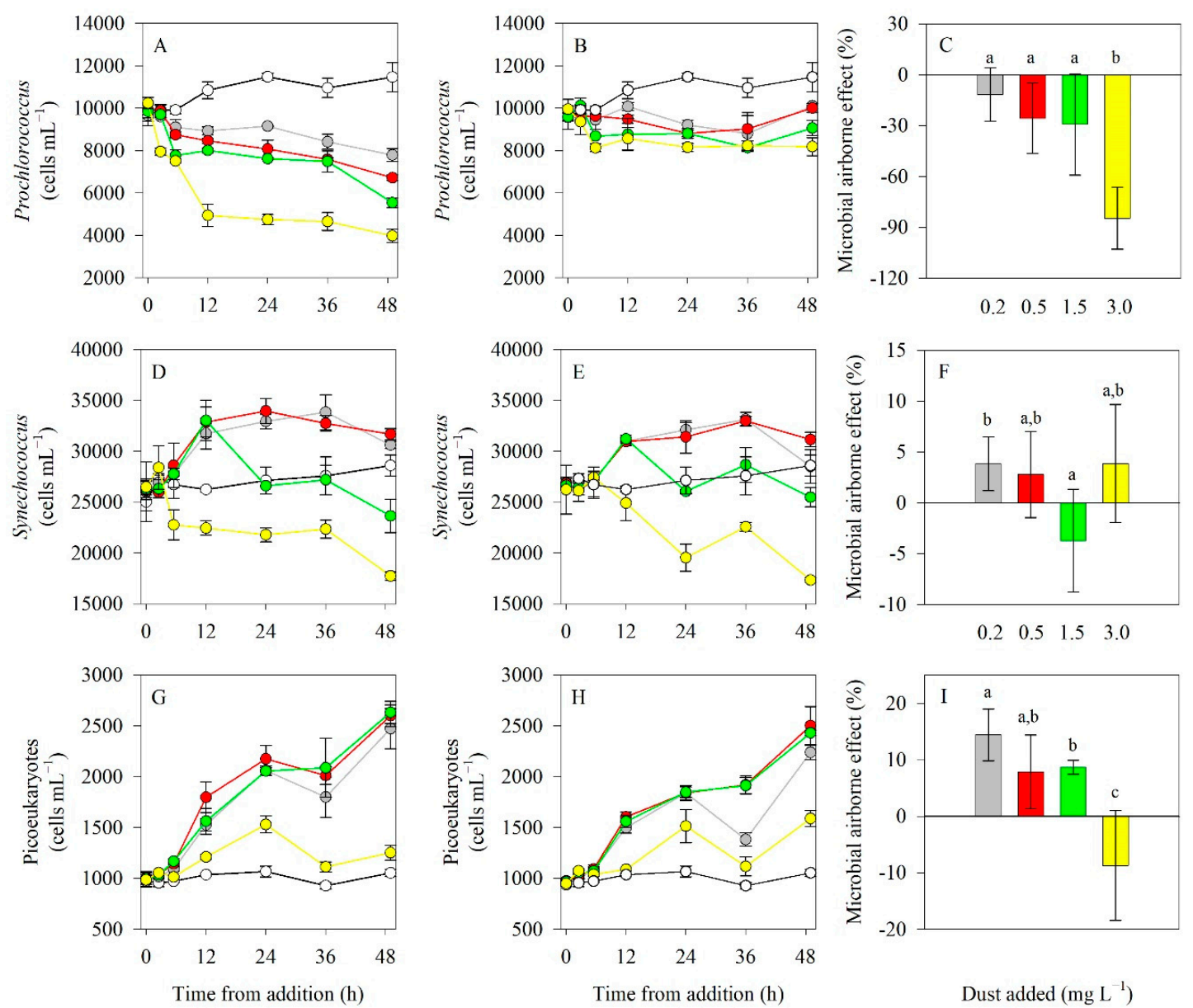

Figure 5. A dose-dependent response of 'live' or 'UV-killed' aerosol addition on Prochlorococcus (A-C), Synechococcus (D-F) and picoeukaryotes (G-I) abundances in samples collected in the SE Mediterranean Sea following 'live aerosol' (A,D,G) or 'UV-killed aerosol' (B,E,H) addition; and the net contribution of airborne microbes to the overall response $(\mathbf{C}, \mathbf{F}, \mathbf{I})$. The different colors represent the concentrations of dust added to the seawater: $0.2 \mathrm{mg} \mathrm{L}^{-1}$ (gray), $0.5 \mathrm{mg} \mathrm{L}^{-1}$ (red), $1.5 \mathrm{mg} \mathrm{L}^{-1}$ (green), $3 \mathrm{mg} \mathrm{L}^{-1}$ (yellow) and no addition (white). ${ }^{*} p<0.05,{ }^{* *} p<0.01(\mathrm{n}=3)$.

\subsection{The Relationship between Aerosol Deposition and Surface Cyanobacterial Populations across the} Mediterranean Sea during Spring

In addition to the microcosm experiments detailed above, we also examined if and how natural Prochlorococcus (as well as Synechococcus and total phytoplankton biomass) at the surface Mediterranean Sea may be affected/unaffected by aerosols. Aerosol and surface water samples collected during the spring throughout the Mediterranean Sea show a high concentration of aluminum and 'aerosol optical depth' (AOD) (Figure 6A) compared to open ocean settings like the North and South Atlantic $(P<0.05)$ [43]. The AOD and aluminum levels were linearly and positively correlated $(R=0.59, p=0.006, n=21)$, suggesting a high contribution of desert-dust aerosols [29,31]. In general, surface-water in-situ Prochlorococcus abundances are low in the Mediterranean water compared to the North and Tropical Atlantic Ocean [1] and shows no spatial trend within the basin (Figure 6B, $R=-0.28, p=0.62)$. This is in contrast to the east-west cross-basin gradient of increased abundance of Synechococcus (Figure 6C, $R=-0.74, p<0.01$ ) and chlorophyll- $a$ concentrations (Figure 6D, $R=0.79$, $p<0.01$ ) westward [28]. We surmise that the sensitivity of Prochlorococcus to airborne biological agents such as viruses or vesicles we observed in our bioassay experiments may explain the relatively low surface water abundance of Prochlorococcus throughout the Mediterranean basin and the absence of an east-west gradient in their abundance, especially during springtime when atmospheric aerosol levels 
are relatively high [29]. The lack of the expected fertilization effect of aerosol addition on Prochlorococcus was also demonstrated in other onboard microcosm experiments from the offshore waters of the Levantine basin (Eastern Mediterranean Sea) [14], highlighting the negative impact (40-50\% reduction in cell abundance) of atmospheric aerosols on ambient Prochlorococcus populations (Figure 6E,F).
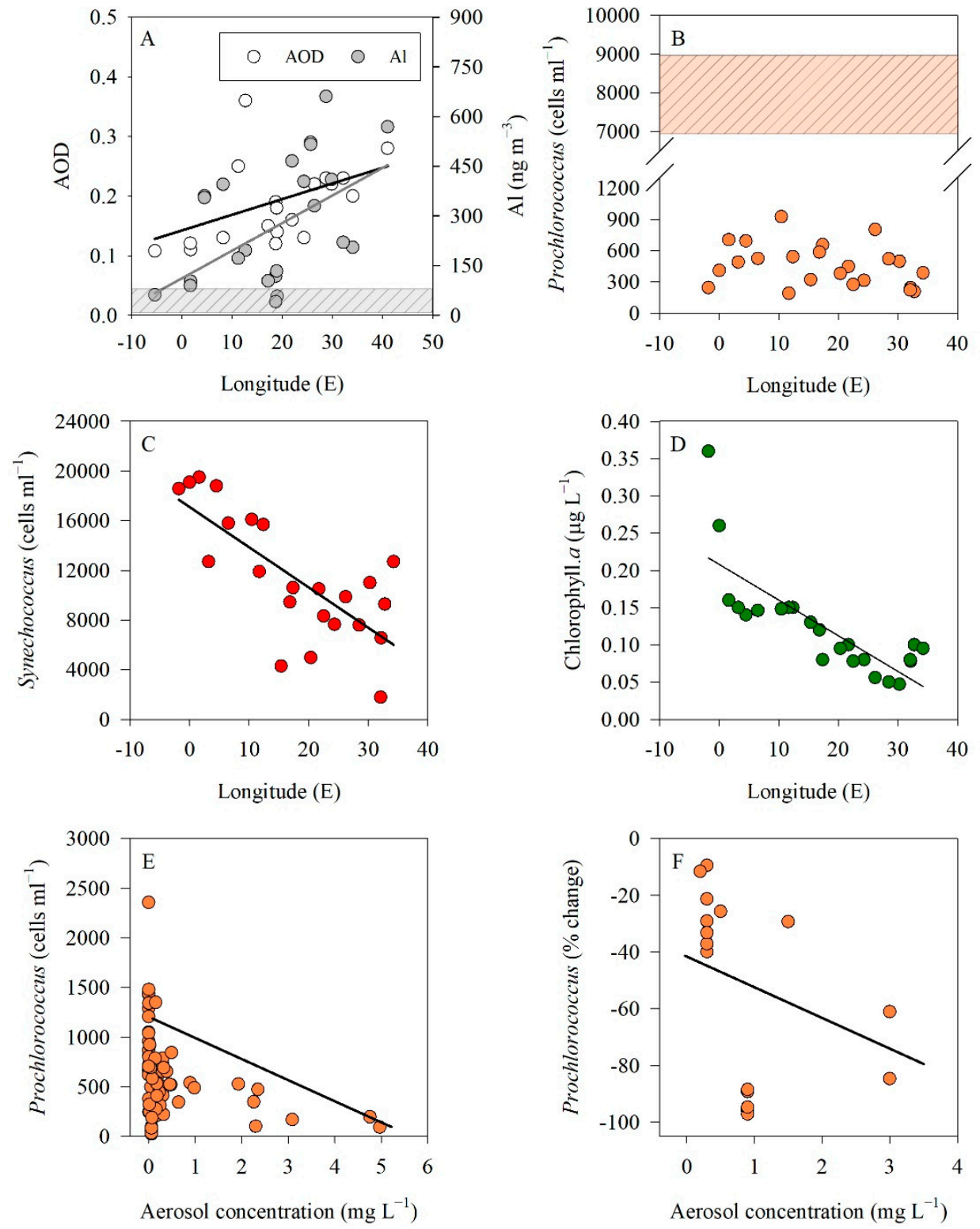

Figure 6. Longitudinal dispersal of Saharan dust and ultra-phytoplankton along the Mediterranean Sea. (A) Spatial distribution of Aerosol Optical Depth at $550 \mathrm{~nm}$ and Al concentration (compiled from [24]). The striped area represents the 'typical' Al background in the North and South Atlantic with no dust storm episodes [43]. The climatological global average AOD over the ocean (excluding polar regions) is $\sim 0.12$ [38]. (B) Surface ( $\sim 5 \mathrm{~m})$ Prochlorococcus abundance along the ship track throughout the Mediterranean Sea during April 2011 [28]. The striped area represents the 'typical' Prochlorococcus abundance in the surface (0-45 m) of the North and Tropical Atlantic [1]. (C) Surface ( 5 m) Synechococcus abundance [28]; and (D) Surface ( $\sim 5 \mathrm{~m})$ chlorophyll- $a$ biomass [28]. (E) The relationship between Prochlorococcus and aerosol dry deposition. Prochlorococcus data was compiled from [13-17,28,44] and this study. (F) The corresponding \% change in Prochlorococcus abundance to aerosol addition (Herut et al., 2005; Chung et al., 2011 and this study). The black lines in panels A, C, D, and F show the linear relationship between variables. 


\section{Discussion}

Marine photosynthesis in LNLC oceans is dominated by single-cell cyanobacteria, where Prochlorococcus is usually one of the most abundant taxa [1,2]. Our results suggest that surface-water Prochlorococcus biomass may be top-down regulated by viruses or other dust-borne biological agents such as extracellular vesicles associated with atmospheric aerosols either as free viruses/vesicles or within infected airborne Prochlorococcus cells, in addition to their role as sources of limiting nutrients (e.g., N, P and Fe) [11,29,45]. Vesicles are small-sized ( 20 to $200 \mathrm{~nm}$ in diameter), spherical, lipid membrane-bound structures, which enable microbes, including Prochlorococcus, to interact with their surroundings, and are also involved in pathogenesis, virulence, nutrient acquisition, biofilm formation and cellular defense $[46,47]$. Vesicles release is believed to be regulated by stress conditions and other environmental factors [48] and may, therefore, play a significant role in the ecology of marine microbial ecosystems [5,47]. Biller et al., [5] reported that vesicles contain a diverse set of proteins, including nutrient transporters and porins that may be used to increase nutrient uptake in LNLC regions. Prochlorococcus-specific vesicles may act the increase the uptake of dust-born trace metals by Prochlorococcus cells. Thus, airborne vesicles can indirectly negatively affect Prochlorococcus through facilitating the increased uptake of toxic-levels of trace metals [18].

Declines in abundances following aerosol additions were previously reported for Prochlorococcus in the tropical northeast Atlantic [15], the Western Atlantic Ocean [16], the northwest Pacific Ocean, [13], the northern Red Sea [17] and the offshore waters of the southeastern Mediterranean Sea [14]. These previous reports attributed the decline in Prochlorococcus abundance solely to toxic quantities of trace metals (such as $\mathrm{Cu}$ ) leached from the aerosols [18,49], ignoring potential interactions with airborne microbes and/or other biological agents. Our results clearly indicate that airborne biological agents may impose additional negative effects. Based on these results, we hypothesize that Prochlorococcus abundance in marine oligotrophic provinces may be negatively affected by airborne biological agents. This 'biological' impact can rival the 'chemical' effects (i.e., nutrient fertilization or metal toxicity) on Prochlorococcus abundances (Figures 3 and 5). Similarly, airborne viruses were reported to terminate an Emiliania huxleyi bloom (coccolithophores, unicellular eukaryotic algae) in the North Atlantic [27]. Indeed, bacteriophages are abundant in seawater and have been observed in Saharan top-soils [22,25] — a well-recognized source of aerosols above the Mediterranean Sea [50]. We postulate that in LNLC areas subjected to relatively high atmospheric dry deposition, where the standing stock of biomass is low and cyanobacteria are the dominating autotrophic organisms (i.e., Mediterranean Sea, N Atlantic Ocean, Red Sea) [11], airborne biological agents may play an important ecological role in controlling the abundance and productivity of selected species. The decrease in Prochlorococcus biomass following aerosol deposition, while no similar trend was observed for other primary producers such as Synechococcus and picoeukaryotes (Figure 5, and see [17]), affect the diversity and distribution of primary producers and may ultimately affect top-down grazing by higher trophic levels [51]. These ecosystem changes may also impact the rate of carbon flux from the euphotic layer to the deep-aphotic waters, as species-dependent cell size potentially affects sinking rates [52].

The Mediterranean Sea may serve as a natural laboratory for oligotrophic LNLC marine provinces impacted by relatively high background levels and intense events of mineral-aerosols depositions $[29,31,53]$. We hypothesize that the species-dependent impact of bio-aerosols may explain the bias in the Prochlorococcus spatial (longitudinal) trend in abundance in the Mediterranean as compared to Synechococcus and chlorophyll-a (Figure 6 and [28]). In summer, a period in which aerosol levels were relatively low across the Mediterranean Sea (June-July 2008, the BOUM campaign [54]), surface Prochlorococcus abundances were higher, and exhibited a weak, yet notable, spatial gradient (i.e., higher values in the western basin over the eastern, in accordance with the Mediterranean Sea general anti-estuarine circulation; [55]). The negative relationship between Prochlorococcus abundance and the amount of mineral-aerosol concentration added in the bioassay incubations (Figure 6E) suggests that an aerosol concentration of $\sim 0.6 \mathrm{mg} \mathrm{L}^{-1}$ would result in a $50 \%$ decrease in Prochlorococcus abundance (calculated based on the assumption of the linear correlation equation established in Figure 6F: 
$y=24.5 \mathrm{x}-33.6$, where $\mathrm{y}$ stand for Prochlorococcus abundance and the $\mathrm{x}$ for aerosol concentration, $R=-0.52, p=0.03$ ). We surmise that airborne viral lysis or vesicles' effects may regulate the surface-water Prochlorococcus population across the Mediterranean Sea during seasons with relatively high aerosol deposition. Our results clearly indicate that bio-aerosols affect, at least to some extent, primary production in this LNLC system. It is to be noted, though, that some viruses may infect both Prochlorococcus and Synechococcus [56,57]. Here, however, no such response was observed (Figure 5), suggesting that only Prochlorococcus-specific viruses/vesicles were delivered with the specific aerosol sample used in our study. Nevertheless, much remains to be elucidated concerning the potential contribution of airborne vesicles/viruses on marine bacteria.

\section{Conclusions}

Aerosol deposition to the surface LNLC oceans is an important source of limiting nutrient to phytoplankton (e.g., N, P and Fe), yet its in situ consequence on autotrophic and heterotrophic prokaryotic microorganisms is not always a positive fertilization effect (e.g., cells increase, enhanced production). Here, we show that airborne viruses or other biological agents such as extracellular vesicles may play a pivotal role in controlling the abundance and productivity of select cyanobacterial species. Specifically, we show that the decline in Prochlorococcus abundance often observed in the surface of the LNLC oceans following dust deposition may be attributed to airborne biological components in aerosols in addition to the effects of chemical toxicity. This observation differs from previous studies who hypothesized that this phenomenon is governed solely by toxic quantities of trace metals (such as $\mathrm{Pb}$ or $\mathrm{Cu}$ ) leached from the aerosols. Further, the literature surveyed in conjunction with our microcosm results suggests that significant dust storms supplying $\sim 0.6 \mathrm{mg} \mathrm{L}^{-1}$ to the upper mixed layer may result in a Prochlorococcus cell loss of $\sim 50 \%$, thereby affecting not only autotrophic microbial composition (e.g., Synechococcus > Prochlorococcus) but potentially also primary productivity rates.

Finally, the impact of atmospheric aerosol deposition will likely become even more important in the future, as many climate models predict enhanced desertification and reduction in soil humidity, resulting in larger amounts of mineral aerosols [58] and probably more intense transport of airborne viruses/vesicles (and other microorganisms). It is suggested to further study the potential ecological role and cell interactions of bio-aerosols in LNLC marine environments through field (on spatial scales), laboratory (e.g., virus isolation, viral gene expression, viral half-life under different atmospheric conditions, different methods to remove/shut down airborne microbial viability than UV light, vesicle role, etc.) and model simulations.

Supplementary Materials: The following are available online at http://www.mdpi.com/2073-4433/11/5/540/s1, Figure S1: Air mass back trajectories derived from backward trajectories model NOAA/ARL HYSPLIT-4 (www.noaa.gov) showing the course and origin of the aerosol used for the laboratory and field experiments $72 \mathrm{~h}$ prior its collection. The different colors show the altitude of the air masses during transport; $100 \mathrm{~m}$ (green), $250 \mathrm{~m}$ (blue) and $500 \mathrm{~m}$ (red). More details can be found in the lower panel, Figure S2: Prokaryotes (bacteria and archaea) abundance in sterile filtered seawater (FSW, grey, $0.22 \mu \mathrm{m}$ ) following addition of 'UV-killed' (white, $48 \mathrm{~h}$ ) and 'live' (yellow) aerosols collected in February 2015. Cells were first stained with the nucleic acid SYTO9 for 10 min in the dark before counted using an Attune®Acoustic Focusing Flow Cytometer (Applied Biosystems) equipped with

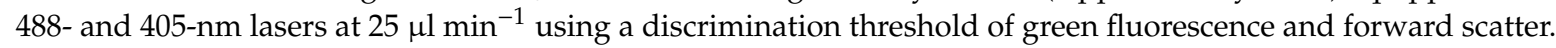
The letters above the bars represent statistically significant differences (ANOVA, $P<0.05$ ) for mean values of prokaryotes in the different treatments $(n=3)$.

Author Contributions: Conceptualization, E.R., B.H. and A.P.; Formal analysis, E.R., A.P., E.B.-Z., F.M.R. and P.X.; Investigation, E.R., E.M., E.B.-Z. and B.H.; Project administration, E.R. and B.H.; Writing - original draft, E.R., A.P. and B.H. All authors have read and agreed to the published version of the manuscript.

Funding: This study was supported by the Israel Science Foundation (grant \#1211/17) to B.H and E.R and by the NSF-OCE (grant \#0850467) to A.P. We also acknowledge the TRACOMED project to B.H and E.R.

Acknowledgments: The authors gratefully acknowledge Daniel Sher from Haifa University for providing the Prochlorococcus MED4 cultures.

Conflicts of Interest: The authors declare that the research was conducted in the absence of any potential conflict of interest. 


\section{References}

1. Partensky, F.; Hess, W.R.; Vaulot, D. Prochlorococcus, a marine photosynthetic prokaryote of global significance. Microbiol. Mol. Biol. Rev. 1999, 63, 106-127. [CrossRef] [PubMed]

2. Flombaum, P.; Gallegos, J.L.; Gordillo, R.A.; Rincón, J.; Zabala, L.L.; Jiao, N.; Karl, D.; Li, W.; Lomas, M.; Veneziano, D.; et al. Present and future global distributions of the marine Cyanobacteria Prochlrococcus and Synechococcus. Proc. Natl. Acad. Sci. USA 2013, 110, 9824-9829. [CrossRef] [PubMed]

3. Kent, A.G.; Dupont, C.L.; Yooseph, S.; Martiny, A.C. Global biogeography of Prochlorococcus genome diversity in the surface ocean. ISME J. 2016, 10, 1856-1865. [CrossRef] [PubMed]

4. Mann, N.H. The third age of phage. PLoS Biol. 2005, 3, 0753-0755. [CrossRef]

5. Biller, S.J.; Schubotz, F.; Roggensack, S.E.; Thompson, A.W.; Summons, R.E.; Chisholm, S.W. Bacterial vesicles in marine ecosystems. Science 2014, 343, 183-186. [CrossRef]

6. Baudoux, A.C.; Veldhuis, M.J.W.; Noordeloos, A.A.M.; Van Noort, G.; Brussaard, C.P.D. Estimates of virus vs. grazing induced mortality of picophytoplankton in the North Sea during summer. Aquat. Microb. Ecol. 2008, 52, 69-82. [CrossRef]

7. Rivera, J.; Cordero, R.J.B.; Nakouzi, A.S.; Frases, S.; Nicola, A.; Casadevall, A. Bacillus anthracis produces membrane-derived vesicles containing biologically active toxins. Proc. Natl. Acad. Sci. USA 2010, 107, 19002-19007. [CrossRef]

8. Manning, A.J.; Kuehn, M.J. Contribution of bacterial outer membrane vesicles to innate bacterial defense. BMC Microbiol. 2011, 11, 258. [CrossRef]

9. DuRand, M.; Olson, R.; Chisholm, S. Abundance of picophytoplankton in the subsurface chlorophyll maximum layer in sub-tropical and tropical waters. Deep Sea Res. Part II Top. Stud. Oceanogr. 2001, 48, 1983-2003. [CrossRef]

10. Grossowicz, M.; Roth-Rosenberg, D.; Aharonovich, D.; Silverman, J.; Follows, M.J.; Sher, D. Prochlorococcus in the lab and in silico: The importance of representing exudation. Limnol. Oceanogr. 2017, 62, 818-835. [CrossRef]

11. Guieu, C.; Aumont, O.; Paytan, A.; Bopp, L.; Law, C.S.; Mahowald, N.; Achterberg, E.P.; Marañón, E.; Salihoglu, B.; Crise, A.; et al. The significance of the episodic nature of atmospheric deposition to Low Nutrient Low Chlorophyll regions. Glob. Biogeochem. Cycles 2014, 28, 1179-1198. [CrossRef]

12. Chien, C.; Mackey, K.R.; Dutkiewicz, S.; Mahowald, N.M.; Prospero, J.M.; Paytan, A. Effects of african dust deposition on phytoplankton in the Western Tropical Atlantic Ocean off Barbados. Glob. Biogeochem. Cycles 2016, 30, 716-734. [CrossRef]

13. Chung, C.C.; Chang, J.; Gong, G.C.; Hsu, S.C.; Chiang, K.P.; Liao, C.W. Effects of Asian dust storms on Synechococcus populations in the Subtropical Kuroshio current. Mar. Biotechnol. 2011, 13, 751-763. [CrossRef] [PubMed]

14. Herut, B.; Zohary, T.; Krom, M.D.D.; Mantoura, R.F.C.; Pitta, P.; Psarra, S.; Rassoulzadegan, F.; Tanaka, T.; Frede Thingstad, T. Response of East Mediterranean surface water to Saharan dust: On-board microcosm experiment and field observations. Deep. Res. Part II Top. Stud. Oceanogr. 2005, 52, 3024-3040. [CrossRef]

15. Hill, P.G.; Zubkov, M.V.; Purdie, D.A. Differential responses of Prochlorococcus and SAR11-dominated bacterioplankton groups to atmospheric dust inputs in the tropical Northeast Atlantic Ocean. FEMS Microbiol. Lett. 2010, 306, 82-89. [CrossRef]

16. Borchardt, T.; Fisher, K.V.; Ebling, A.M.; Westrich, J.R.; Xian, P.; Holmes, C.D.; Landing, W.M.; Lipp, E.K.; Wetz, M.S.; Ottesen, E.A. Saharan dust deposition initiates successional patterns among marine microbes in the Western Atlantic. Limnology 2019, 9999, 1-13. [CrossRef]

17. Mescioglu, E.; Rahav, E.; Frada, M.J.; Rosenfeld, S.; Raveh, O.; Galletti, Y.; Santinelli, C.; Herut, B.; Paytan, A. Dust-Associated Airborne Microbes Affect Primary and Bacterial Production Rates, and Eukaryotes Diversity, in the Northern Red Sea: A Mesocosm Approach. Atmo 2019, 10, 358. [CrossRef]

18. Paytan, A.; Mackey, K.R.M.; Chen, Y.; Lima, I.D.; Doney, S.C.; Mahowald, N.; Labiosa, R.; Post, A.F.A.F. Toxicity of atmospheric aerosols on marine phytoplankton. Proc. Natl. Acad. Sci. USA. 2009, 106, 4601-4605. [CrossRef]

19. Gat, D.; Mazar, Y.; Cytryn, E.; Rudich, Y. Origin-dependent variations in the atmospheric microbiome community in Eastern Mediterranean dust storms. Environ. Sci. Technol. 2017, 51, 6709-6718. [CrossRef] 
20. Griffin, D.W.; Kubilay, N.; Koçak, M.; Gray, M.A.; Borden, T.C.; Shinn, E.A. Airborne desert dust and aeromicrobiology over the Turkish Mediterranean coastline. Atmos. Environ. 2007, 41, 4050-4062. [CrossRef]

21. Mayol, E.; Arrieta, J.M.; Jiménez, M.A.; Martínez-Asensio, A.; Garcias-Bonet, N.; Dachs, J.; González-Gaya, B.; Royer, S.J.; Benítez-Barrios, V.M.; Fraile-Nuez, E.; et al. Long-range transport of airborne microbes over the global tropical and subtropical ocean. Nat. Commun. 2017, 8, 1-8. [CrossRef] [PubMed]

22. Prigent, M.; Leroy, M.; Confalonieri, F.; Dutertre, M.; DuBow, M.S. A diversity of bacteriophage forms and genomes can be isolated from the surface sands of the Sahara Desert. Extremophiles 2005, 9, 289-296. [CrossRef] [PubMed]

23. Rahav, E.; Ovadia, G.; Paytan, A.; Herut, B. Contribution of airborne microbes to bacterial production and N2 fixation in seawater upon aerosol deposition. Geophys. Res. Lett. 2016, 43, 1-9. [CrossRef]

24. Mescioglu, E.; Rahav, E.; Belkin, N.; Xian, P.; Eizenga, J.; Vichik, A.; Herut, B.; Paytan, A. Aerosol microbiome over the Mediterranean Sea: Diversity and abundance. Atmosphere 2019, 10, 440. [CrossRef]

25. Reche, I.; D'Orta, G.; Mladenov, N.; Winget, D.M.; Suttle, C.A. Deposition rates of viruses and bacteria above the atmospheric boundary layer. ISME J. 2018, 12, 1154-1162. [CrossRef] [PubMed]

26. Womack, A.M.; Bohannan, B.J.M.; Green, J.L. Biodiversity and biogeography of the atmosphere. Philos. Trans. R. Soc. Lond. B: Biol. Sci. 2010, 365, 3645-3653. [CrossRef]

27. Sharoni, S.; Trainic, M.; Schatz, D.; Lehahn, Y.; Flores, M.J.; Bidle, K.D.; Ben-Dor, S.; Rudich, Y.; Koren, I.; Vardi, A. Infection of phytoplankton by aerosolized marine viruses. Proc. Natl. Acad. Sci. USA 2015, 112, 6643-6647. [CrossRef]

28. Rahav, E.; Herut, B.; Levi, A.; Mulholland, M.R.; Berman-Frank, I. Springtime contribution of dinitrogen fixation to primary production across the Mediterranean Sea. Ocean Sci. 2013, 9, 489-498. [CrossRef]

29. Herut, B.; Collier, R.; Krom, M.D. The role of dust in supplying nitrogen and phosphorus to the southeast Mediterranean. Limnol. Oceanogr. 2002, 47, 870-878. [CrossRef]

30. Kocak, M.; Kubilay, N.; Herut, B.; Nimmo, M. Dry atmospheric fluxes of trace metals (Al, Fe, Mn, Pb, Cd, Zn, $\mathrm{Cu}$ ) over the Levantine Basin: A refined assessment. Atmos. Environ. 2005, 39, 7330-7341. [CrossRef]

31. Herut, B.; Rahav, E.; Tsagaraki, T.M.; Giannakourou, A.; Tsiola, A.; Psarra, S.; Lagaria, A.; Papageorgiou, N.; Mihalopoulos, N.; Theodosi, C.N.; et al. The potential impact of Saharan dust and polluted aerosols on microbial populations in the east Mediterranean Sea, an overview of a mesocosm experimental approach. Front. Mar. Sci. 2016, 3, 226. [CrossRef]

32. Rahav, E.; Paytan, A.; Mescioglu, E.; Galletti, Y.; Rosenfeld, S.; Raveh, O.; Santinelli, C.; Ho, T.; Herut, B. Airborne microbes contribute to N2 fixation in surface water of the Northern Red Sea. Geophys. Res. Lett. 2018, 2-10. [CrossRef]

33. Siokou-Frangou, I.; Christaki, U.; Mazzocchi, M.G.; Montresor, M.; Ribera d'Alcalá, M.; Vaqué, D.; Zingone, A. Plankton in the open Mediterranean Sea: A review. Biogeosciences 2010, 7, 1543-1586. [CrossRef]

34. Berman-Frank, I.; Rahav, E. Nitrogen fixation as a source for new production in the Mediterranean Sea: A review. In Life in the Mediterranean Sea: A Look at Habitat Changes; Nova Science Publishers: New York, NY, USA, 2012; pp. 199-226.

35. Hazan, O.; Silverman, J.; Sisma-Ventura, G.; Ozer, T.; Gertman, I.; Shoham-Frider, E.; Kress, N.; Rahav, E. Mesopelagic prokaryotes alter surface phytoplankton production during simulated deep mixing experiments in Eastern Mediterranean Sea waters. Front. Mar. Sci. 2018, 5. [CrossRef]

36. Ridame, C.; Guieu, C. Saharan input of phosphate to the oligotrophic water of the open western Mediterranean Sea. Limnol. Oceanogr. 2002, 47, 856-869. [CrossRef]

37. Rahav, E.; Paytan, A.; Chien, C.; Ovadia, G.; Katz, T.; Herut, B. The impact of atmospheric dry deposition associated microbes on the southeastern Mediterranean Sea surface water following an intense dust storme. Front. Mar. Sci. 2016, 3, 127. [CrossRef]

38. Lynch, P.; Reid, J.S.; Westphal, D.L.; Zhang, J.; Hogan, T.F.; Hyer, E.J.; Curtis, C.A.; Hegg, D.A.; Shi, Y.; Campbell, J.R.; et al. An 11-year global gridded aerosol optical thickness reanalysis (v1.0) for atmospheric and climate sciences. Geosci. Model Dev. 2016, 9, 1489-1522. [CrossRef]

39. Prospero, J.M.; Blades, E.; Mathison, G.; Naidu, R. Interhemispheric transport of viable fungi and bacteria from Africa to the Caribbean with soil dust. Aerobiologia 2005, 21, 1-19. [CrossRef]

40. Moore, L.R.; Coe, A.; Zinser, E.R.; Saito, M.A.; Sullivan, M.B.; Lindell, D.; Frois-Moniz, K.; Waterbury, J.; Chisholm, S.W. Culturing the marine cyanobacterium Prochlorococcus. Limnol. Oceanogr. Methods 2007, 5, 353-362. [CrossRef] 
41. Raveh, O.; David, N.; Rilov, G.; Rahav, E. The temporal dynamics of coastal phytoplankton and bacterioplankton in the eastern mediterranean sea. PLOS ONE 2015, 10. [CrossRef]

42. Vaulot, D.; Marie, D. Diel variability of photosynthetic picoplankton in the equatorial Pacific. JGR Ocean. 1999, 104, 3297-3310. [CrossRef]

43. Jickells, T.D.; Baker, A.R.; Chance, R. Atmospheric transport of trace elements and nutrients to the oceans. Philos. Trans. R. Soc. A Math. Phys. Eng. Sci. 2016, 374. [CrossRef] [PubMed]

44. Yogev, T.; Rahav, E.; Bar-Zeev, E.; Man-Aharonovich, D.; Stambler, N.; Kress, N.; Béjà, O.; Mulholland, M.R.; Herut, B.; Berman-Frank, I. Is dinitrogen fixation significant in the Levantine Basin, East Mediterranean Sea? Environ. Microbiol. 2011, 13, 854-871. [CrossRef]

45. Mills, M.M.; Ridame, C.; Davey, M.; La Roche, J.; Geider, R.J. Iron and phosphorus co-limit nitrogen fixation in the eastern tropical North Atlantic. Nature 2004, 429, 292-294. [CrossRef]

46. Ellis, T.N.; Kuehn, M.J. Virulence and Immunomodulatory Roles of Bacterial Outer Membrane Vesicles. Microbiol. Mol. Biol. Rev. 2010, 74, 81-94. [CrossRef]

47. Brown, L.; Wolf, J.M.; Prados-Rosales, R.; Casadevall, A. Through the wall: Extracellular vesicles in Gram-positive bacteria, mycobacteria and fungi. Nat. Rev. Microbiol. 2015, 13, 620-630. [CrossRef]

48. MacDonald, I.A.; Kuehna, M.J. Stress-induced outer membrane vesicle production by Pseudomonas aeruginosa. J. Bacteriol. 2013, 195, 2971-2981. [CrossRef]

49. Mann, E.L.; Ahlgren, N.; Moffett, J.W.; Chisholm, S.W. Copper toxicity and cyanobacteria ecology in the Sargasso Sea. Limnol. Oceanogr. 2002, 47, 976-988. [CrossRef]

50. Herut, B.; Nimmo, M.; Medway, A.; Chester, R.; Krom, M.D. Dry atmospheric inputs of trace metals at the Mediterranean coast of Israel (SE Mediterranean): Sources and fluxes. Atmos. Environ. 2001, 35, 803-813. [CrossRef]

51. Christaki, U. Nanoflagellate predation on auto- and heterotrophic picoplankton in the oligotrophic Mediterranean Sea. J. Plankton Res. 2001, 23, 1297-1310. [CrossRef]

52. Finkel, Z.V.; Beardall, J.; Flynn, K.J.; Quigg, A.; Rees, T.A.V.; Raven, J.A. Phytoplankton in a changing world: Cell size and elemental stoichiometry. J. Plankton Res. 2010, 32, 119-137. [CrossRef]

53. Guieu, C.; Dulac, F.; Ridame, C.; Pondaven, P. Introduction to project DUNE, a DUst experiment in a low nutrient, low chlorophyll ecosystem. Biogeosciences 2014, 11, 425-442. [CrossRef]

54. Gallisai, R.; Peters, F.; Basart, S.; Baldasano, J.M. Mediterranean basin-wide correlations between Saharan dust deposition and ocean chlorophyll concentration. Biogeosci. Discuss. 2012, 9, 8611-8639. [CrossRef]

55. Mella-Flores, D.; Mazard, S.; Humily, F.; Partensky, F.; Mahé, F.; Bariat, L.; Courties, C.; Marie, D.; Ras, J.; Mauriac, R.; et al. Is the distribution of Prochlorococcus and Synechococcus ecotypes in the Mediterranean Sea affected by global warming? Biogeosciences 2011, 8, 2785-2804. [CrossRef]

56. Dekel-Bird, N.P.; Avrani, S.; Sabehi, G.; Pekarsky, I.; Marston, M.F.; Kirzner, S.; Lindell, D. Diversity and evolutionary relationships of T7-like podoviruses infecting marine cyanobacteria. Environ. Microbiol. 2013, 15, 1476-1491. [CrossRef]

57. Sullivan, M.B.; Waterbury, J.B.; Chisholm, S.W. Cyanophage infecting the oceanic cyanobacterium Prochlorococcus. Nature 2003, 424, 1047-1051. [CrossRef]

58. Prospero, J.M.; Lamb, P.J. African droughts and dust transport to the Caribbean: Climate change implications. Science 2003, 302, 1024-1027. [CrossRef]

(C) 2020 by the authors. Licensee MDPI, Basel, Switzerland. This article is an open access article distributed under the terms and conditions of the Creative Commons Attribution (CC BY) license (http://creativecommons.org/licenses/by/4.0/). 